\title{
IWMPRAISE - AN EU HORIZON 2020 PROJECT PROVIDING INTEGRATED WEED MANAGEMENT SOLUTIONS TO EUROPEAN FARMERS
}

Per Kudsk', Mette Sønderskov', Ludovic Bonin², Jose L. Gonzalez-Andujar³, Jens Erik Jensen", Bo Melander', Camilla Moonen ${ }^{5}$, Marleen Riemens ${ }^{6}$, Maurizio Sattin ${ }^{7}$, Urs Schaffner ${ }^{8}$ and Jonathan Storkey'; 'Aarhus University, Dept. of Agroecology, Denmark, ${ }^{2}$ ARVALIS, Boigneville, France, ${ }^{3} \mathrm{CSIC}$, Instituto de Agricultura Sostenible, Spain, ${ }^{4}$ SEGES, Skejby, Denmark, ${ }^{5}$ Scuola Superior Sant'Anna, Institute of Life Sciences, Pisa, Italy, ${ }^{6}$ Wageningen University \& Research, Netherlands, ${ }^{7} \mathrm{CNR}$, Institute for Sustainable Plant Protection, Padova, Italy, ${ }^{8}$ Agroscope, Forage Production and Grassland Systems, Zurich, Switzerland, ${ }^{8} \mathrm{CABI}$ Switzerland, Delemont, Switzerland, ${ }^{9}$ Rothamsted Research, Harpenden, UK

IWMPRAISE is the first EU Framework Research project focusing solely on weed management. Thirty-eight partners in eight European countries are working together on developing integrated weed management strategies for agricultural and horticultural crops. Per Kudsk, the coordinator of IWMPRAISE, and the work package leaders present the project, the on-going studies and some of the early outputs.

Keywords: herbicides, non-chemical weed control, cultural weed control, biological control, soil tillage
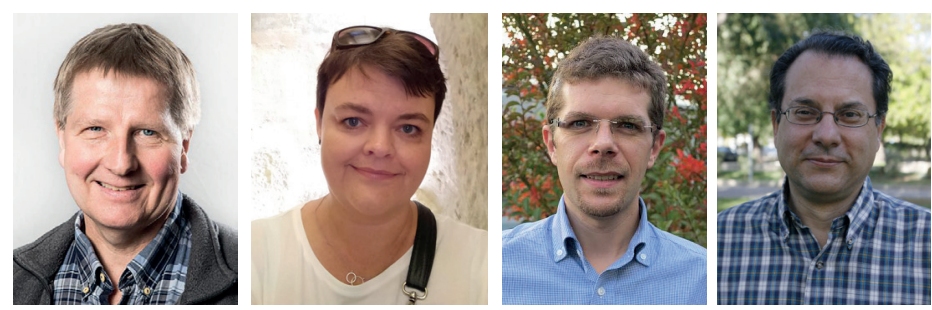

Per Kudsk

Mette Sønderskov

Ludovic Bonin Jose GonzalezAndujar

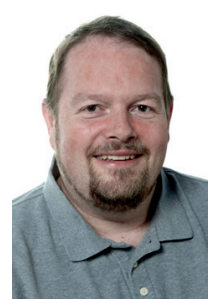

Jens Jensen

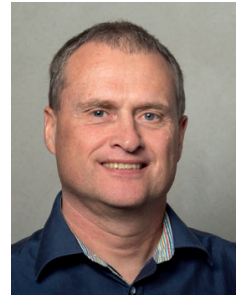

Bo Melander

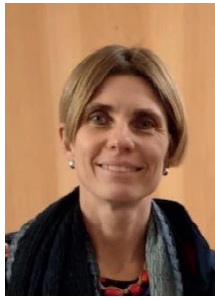

Camilla Moonen

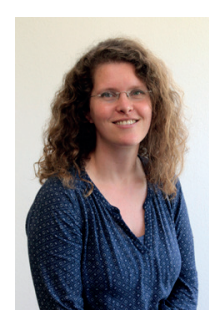

Marleen Riemens

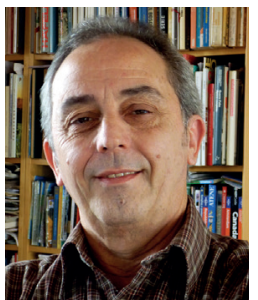

Maurizio Sattin

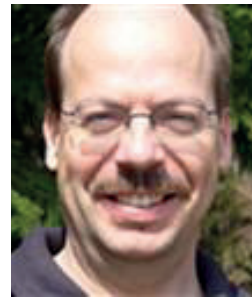

Urs Schaffner

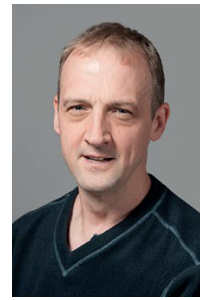

Jonathan Storkey

\section{Introduction}

Weeds are ubiquitous and cause substantial yield losses across all arable and horticultural systems (Oerke, 2006). Currently, the reliance on herbicides is very high in conventional farming systems and in many European countries herbicides are the single most used group of pesticides (https:// appsso.eurostat.ec.europa.eu/nui/show.do?dataset=aei_fm salpest09\&lang=en). There are several reasons for the high herbicide use, such as lack of threshold-based spraying decisions (Munier-Jolain et al., 2002) and lack of any single sufficiently effective, readily applicable, cost-effective non-chemical method. Nonetheless, two factors are driving an immediate need to change weed control practices in conventional farming: the rapidly increasing problem of herbicide resistance, exacerbated by the fact that no new herbicide sites of action have been marketed since the early 1980s, and the expectation that many of the currently used herbicides will be withdrawn from the EU market as they do not meet the human and environmental toxicity criteria set out in EU Regulation 1109/2009. In addition to these two immediate concerns, it has also been shown that herbicides have partly been responsible for recent declines in farmland biodiversity and hence a negative impact on the associated ecosystem services (Storkey et al., 2012). The over-reliance on chemical control of weeds has highlighted the need for Integrated Weed Management (IWM) strategies that combine non-chemical management options that reduce either weed density or competition with the crop.

IWMPRAISE is addressing IWM in a broad range of crops (arable, horticultural and perennial herbaceous and woody crops). In contrast to the crop specificity of most herbicides, IWM tends to be more generic in the sense that practices from one crop can often be applied in crops with similar growth habit, growing season and/or grown with the same spatial arrangement. This inspired the adoption of a categorical 


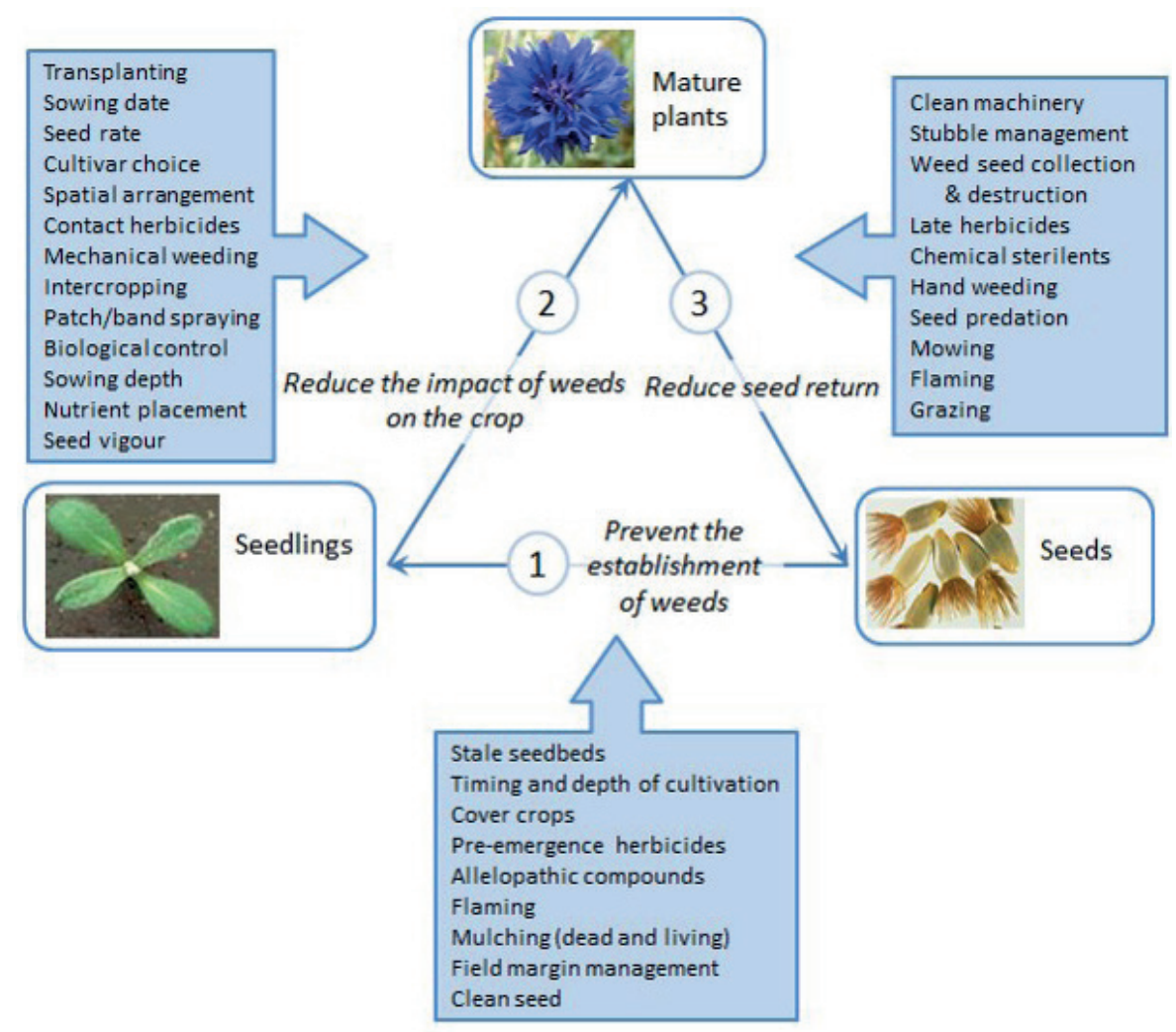

Figure I. IWM framework of IWMPRAISE.

approach with four management scenarios: annually drilled crops in narrow rows (e.g. small grain cereals and oilseed rape), annually drilled crops in wide rows (e.g. maize and field vegetables), perennial herbaceous crops (e.g. grassland and alfalfa) and perennial woody crops (e.g. pomefruit and olive). This allows for extrapolation of the general principles underlying IWM strategies between regions of Europe with due consideration of differences in e.g. climatic conditions. It is important to stress that IWMPRAISE does not disclaim the use of herbicides, but focuses on reducing the reliance on herbicides by complementing them, fully or partly, with nonchemical methods. We envisage that IWM strategies in all crops, at least in the foreseeable future, will be a combination of chemical and non-chemical methods.

IWMPRAISE, like other agricultural related EU Horizon projects, adopted the multi-actor approach, i.e. all stakeholders including end-users are involved in all steps of the project from the planning to the execution and evaluation. This is reflected in the composition of the project consortium consisting of research organisations, advisory services, small and medium sized enterprises (SMEs) producing novel IWM tools and end-user organisations.

The IWMPRAISE framework for IWM is built around the life cycle of weeds and is illustrated in Figure 1. IWMPRAISE is developing effective IWM strategies by adding new tools and developing further existing tools that either: 1) limit weed establishment in the crop from the soil seed bank or subterranean vegetative organs, 2) limit competition for resources such as light, nutrients and water by removing weeds or manipulating the weed flora to reduce their competitive impact and 3) limit return of seeds or vegetative organs to the soil seed/ vegetative organ bank. Some of the main IWM tools limiting weed establishment, competition and seed return are listed in the boxes in Figure 1, but it should be stressed that the lists are not exhaustive.

IWMPRAISE is organised in 10 work packages (WP) (Figure 2). Management scenarios are each represented by one WP (3 to 6) where IWM strategies are designed tested and a preliminary assessment of their performance and costeffectiveness is conducted. For each of the management scenarios research is conducted in at least two countries. In each country, national clusters consisting of researchers, advisors, SMEs, end-users and other relevant stakeholders are responsible for planning and conducting the IWM activities. This approach was chosen to ensure that context-specific IWM strategies considering local conditions are developed and to create a forum for discussions among stakeholders speaking the same language. In WP 3-6, existing and validated IWM tools are combined with the aim to develop novel and efficient IWM strategies. New and more immature tools at an early stage of development are evaluated in WP 2, our "innovation hub". Some of the tools developed in WP 2 are expected to be included in the WP 3-6 activities. Work package 7 is dedicated to developing IWM solutions for non-inversion tillage systems, as weed problems are often exacerbated in these systems (Melander et al., 2013). Furthermore, this WP examines the trade-offs between beneficial effects of non-inversion tillage systems on soil fertility, greenhouse gas emission etc. and potential weed problems. Long-term impacts of IWM on the environment and farming economy are assessed in WP 8 through scenario building and modelling, based on the results generated in WP 2-7. Dissemination is an important output of IWMPRAISE and WP 9 is dedicated to dissemination, training and outreach. For example, all experimental trials are described 


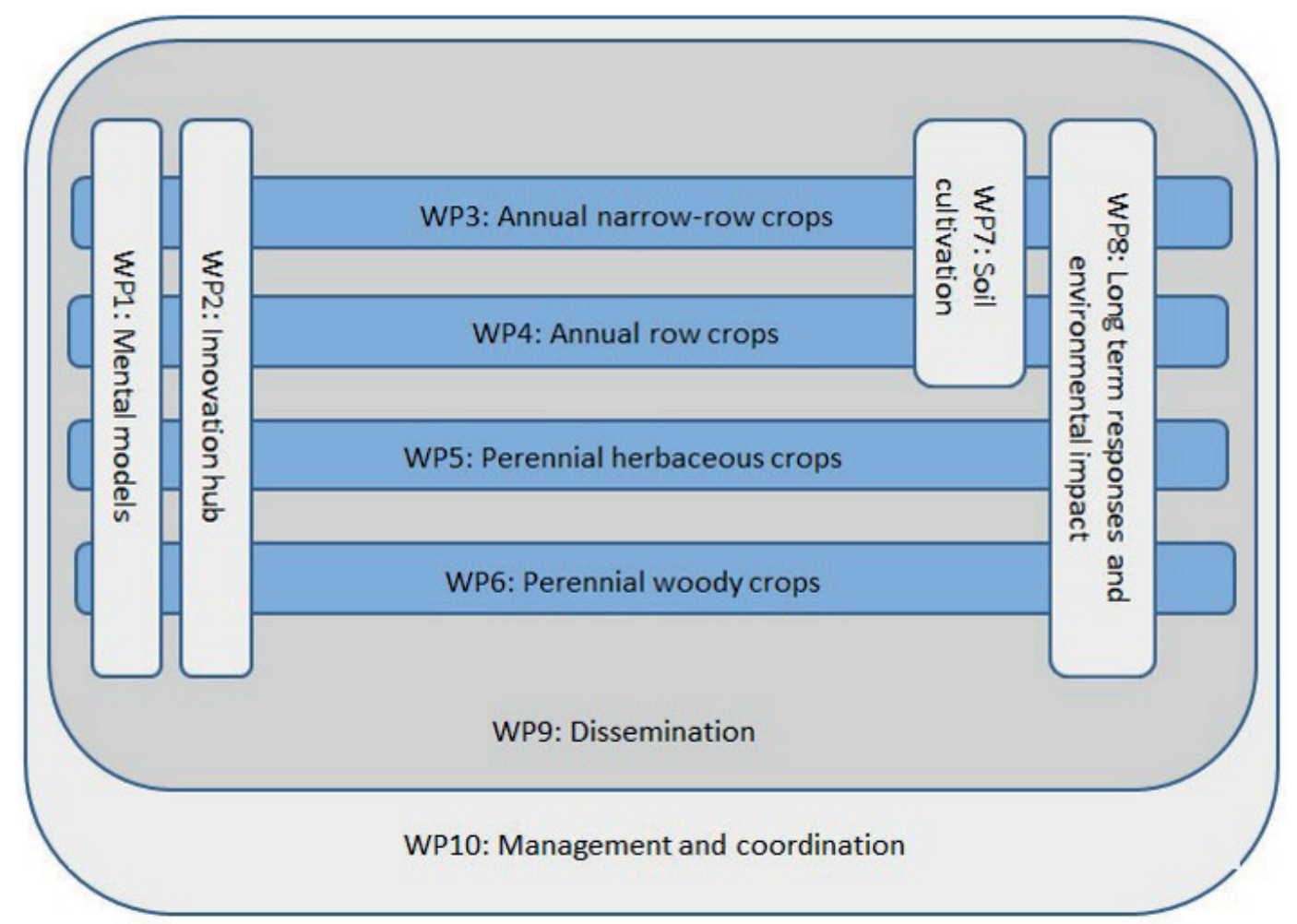

Figure 2. Organisation of IWMPRAISE.

in detail in a yearly booklet that can be downloaded at https:// iwmpraise.eu/publications/. A novelty of IWMPRAISE is the mental modelling in WP 1. Through in-depth interviews and text analysis, the knowledge, beliefs, perceptions and attitudes about IWM of weed experts and end-users in seven of the eight participating countries were mapped.

\section{On-going IWM Activities within the Four Management Scenarios}

The first activity launched in IWMPRAISE was the mental modelling exercise (WP 1) to capture contrasting attitudes to weed management between stakeholders and identify barriers to the uptake of IWM. In a first step, five experts in each country were interviewed. Interviews were recorded, transcribed and then coded by the interviewers using a common coding framework with five pillars of IWM tactics: diverse cropping system; suppressive/tolerant varieties; crop management tactics; targeted control tactics to disturb the life cycle of weeds; and monitoring/evaluation. Based on the outcome, mental models were developed by experts illustrating the frequency different tools were mentioned (an example is shown in Figure 3). The larger the font size, the more often the experts mentioned that particular IWM tool. Subsequently, similar interviews were conducted with end-users and the results of these interviews are currently being processed. Although the mental modelling exercise data have not yet been fully analysed and published, they provided a unique insight into how weed experts and endusers view IWM and its implementation both nationally and Europe-wide. As the interviewers were also involved in WP 3-6 activities, the knowledge collected in WP 1 was applied when the national clusters planned the IWM strategies.
In annually drilled crops in narrow rows, experiments will be conducted through three growing seasons with 2019 being the second. Focus has been on the effect of cultural/ preventive measures such as delayed sowing, false seedbed, crop density, cover crops and management of break crops and targeted control with mechanical weeding (weed hoeing and tine harrowing). In annually drilled crops in wide rows, the focus was mainly on targeted control with inter-row hoeing in combination with band-spraying along the crop row, nonselective herbicides followed by inter-row hoeing and tine harrowing. Anticipating a possible ban on glyphosate in the EU, studies were also conducted comparing pre-sowing mechanical weeding to pre-sowing/pre-emergence glyphosate spraying. It is still too early to draw any conclusions, partly because of two very abnormal growing seasons in both Northern and Southern Europe, which severely affected the growth of both crops and weeds.

Alongside the above-mentioned experiments combining validated IWM tools, as part of the innovation hub, explorative research was conducted with an inter-row cultivator mounted with spray nozzles for simultaneous band spraying, inter-row cultivation with novel shares in small grain cereals and intra-row flame weeding in sugar beet (Figure 4). Inter-row cultivation offers an obvious alternative to chemical weed control in wide row crops but with cameras and other tools for guidance it may also become an alternative to herbicides in annual crops in narrow rows if grown at a slightly wider row distance than the current $12.5 \mathrm{~cm}$. The Harrington Weed Seed Destructor system will also be evaluated for reducing weed seed return to the soil seed bank under European conditions. The Harrington Weed Seed Destructor was developed in Australia and is being used successfully to 


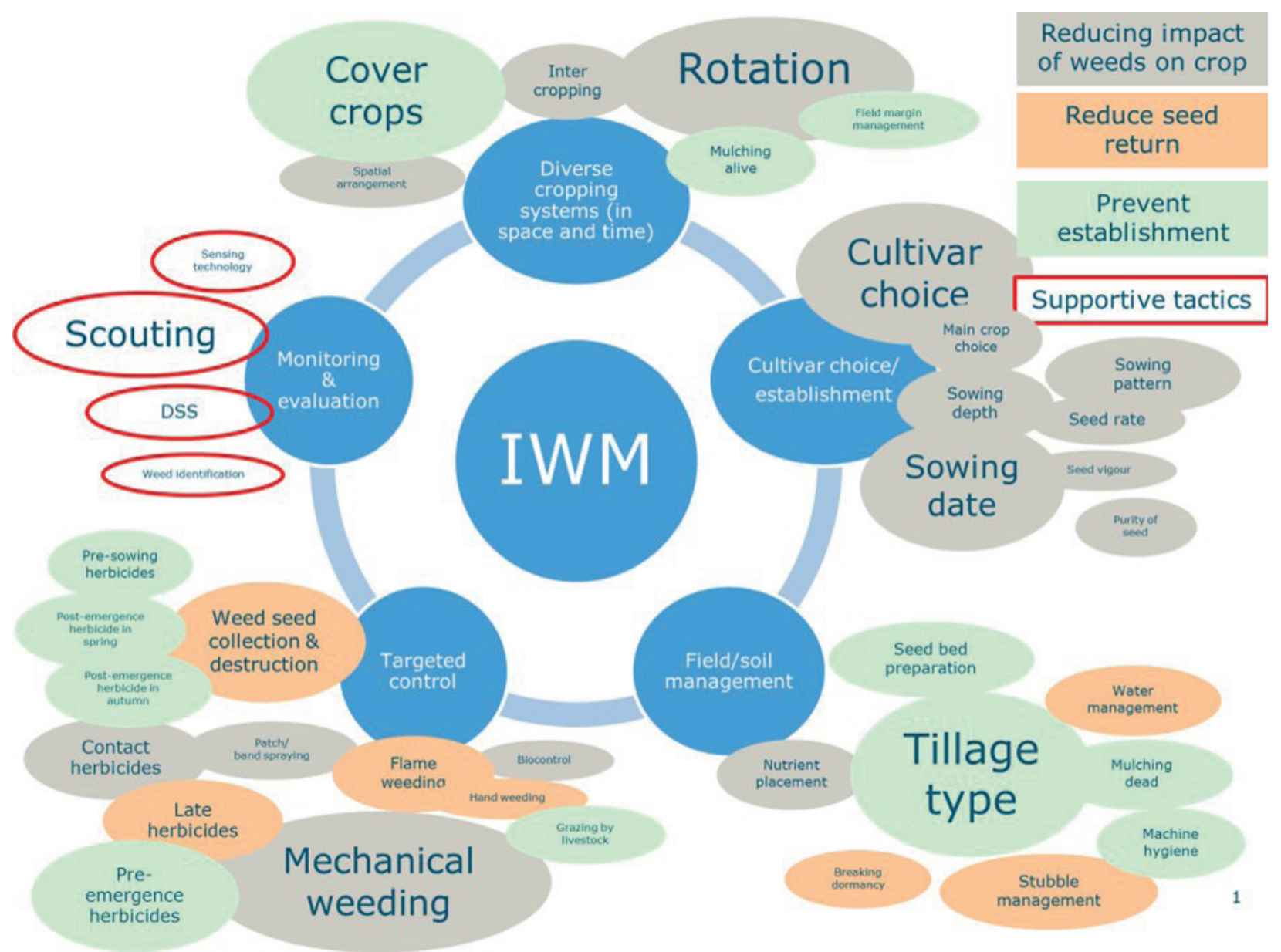

Figure 3. Expert mental model on IWM.The bigger the font the more important the experts found the IWM tool.

combat herbicide resistant ryegrass (Lolium rigidum) (Walsh, 2018). Other innovations explored in the Innovation Hub are the selection of legume cover crop species and varieties most suitable for relay cropping in winter wheat and finding more effective ways of cover crops with a roller crimper by adjusting timing, tractor speed and blade type. These approaches are first tested on-station, and subsequently the most effective solutions are tested in farmer fields in collaboration with the farmers and based on their needs. All these technologies need further development but may be included in the WP 3-4 activities in the coming growing season.

In perennial herbaceous crops, focus is on 1) spot spraying using sensors being developed by one the SME partners, 2) augmentative biocontrol of Rumex spp. and 3) the effect of seed preparation, crop seed rate and seed mix diversity on alleviating weed pressure in newly established pastures. Activities are ongoing and will be continued in the coming years.

In perennial woody crops, inter-row cover crops/living mulches to reduce soil erosion and compaction and to improve biodiversity and intra-row mechanical weed control are in focus as a mean to reduce the reliance on herbicides. Preliminary results provided positive indications for the use of cover crops in semiarid regions where soil conservation and erosion control is crucial. However, a 3-year study is required for verification of these strategies on the agronomic and environmental effects, in order to make better management decisions regarding the use of these techniques by farmers.

\section{Soil Tillage and IWM}

Non-inversion tillage, no-till and conservation tillage offer great advantages, reducing costs of management and improving soil fertility but are often associated with more severe weed problems than inversion tillage (Melander et al., 2013). In particular, the transition phase when switching from ploughing to no ploughing brings problems related to weed control. In total, six IWMPRAISE experiments have been initiated addressing the transition phase. In addition, INRA, one of the French partners has sent out a questionnaire to French farmers practising no-till to collect further information on weed problems encountered during the transition phase. INRA is also conducting a weed flora survey on the same farms and preliminary results revealed a higher species richness with increasing number of years of no-till but no increase in the number of grass weeds or perennial weeds.

Over the last 10-15 years, a large number of long-term experiments comparing non-inversion and inversion tillage have been conducted throughout Europe. The purpose of the experiments has been diverse but in many of the experiments information of occurrence of weeds was collected before and after transition to non-inversion tillage. These data represent a unique source of information on the trade-off between soil tillage and weeds and these data will be collected and a metaanalysis will be conducted testing some of the hypotheses that have been put forward regarding the impact of soil tillage on soil fertility and crop and weed growth. 


\section{IWMPRAISE -AN EU HORIZON 2020 PROJECT}

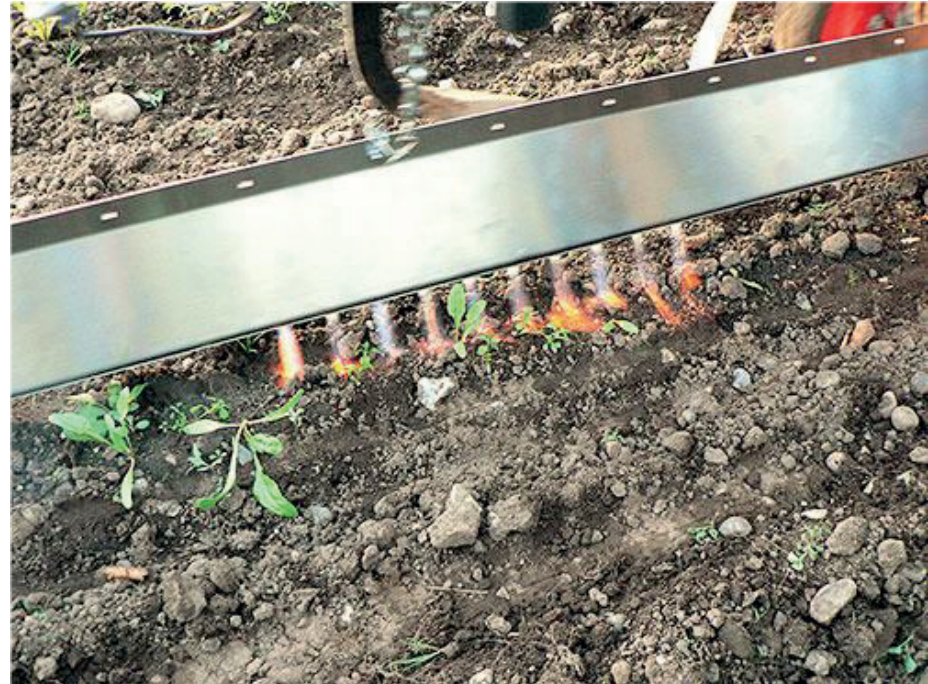

Figure 4. Novel equipment for intra-row flaming in row crops developed by Frank Poulsen Engineering Aps (Photo: Bo Melander, Aarhus University, Denmark).

\section{Long-term Impact of IWM}

Although IWMPRAISE runs for five years, which is longer than most other EU projects, this is not sufficient to document the long-term effects of IWM. Instead, the intention is to predict the long-term effects through scenario building and modelling and this exercise will be based on the results generated in WP 2-7. The focus will be on the effects on weed flora dynamics, the benefits of a more diversified weed flora, the risk of evolution of herbicide resistance and the long-term economic consequences of adopting IWM strategies. Our overall hypothesis is that by adopting IWM it will be possible to increase weed diversity and evenness and at the same time to reduce competitiveness of the weed flora. This will increase biodiversity and potential ecosystem services as well as minimising the impact of the weed flora on crop yield. In so doing, our objective differs from a zero-tolerance or "take no prisoners" strategy currently recommended in Australia and the USA as we assume that the total eradication of weeds is impossible and so aim to reduce their negative impact on the crop while retaining some ecological benefit.

Assessment of the economic consequences is still in its early phase but the overall approach is to describe and evalu- ate the current systems and then assess the effects of replacing herbicide-dominated strategies by IWM strategies in terms of crop yield and costs of weed control in both the short and long term.

\section{Dissemination}

Dissemination, training and outreach are key activities of IWMPRAISE and ample resources are dedicated for this. It was calculated that within the first 18 months of the projects, IWMPRAISE reached a total audience of 210,000 people through communication and arrangements such as field days.

Planning of the dissemination activities is the responsibility of a communication team chaired by the WP 9 leader and consisting of one person from each of the eight participating countries. The project has a website in English (www. iwmpraise.eu), which is linked to national cluster websites (Table 1) where most information is published in the local language but with links to the project. This set-up was chosen because previous experience from other EU projects revealed that language is a major barrier for exchange of information at advisor and end-user level. National websites are typically embedded in relevant existing websites where farmers are seeking information on crop protection. Besides websites, IWMPRAISE is also present on social media such as Facebook, Twitter, Instagram and LinkedIn and furthermore videos are uploaded on YouTube.

An array of information material is available on the websites and social media. We aim to maximise the use of visual aids such as videos and pictures rather than written material but a number of booklets and brochures are available. Of particular note are the inspiration sheets, which are one-page brochures in English with many illustrations providing easy-to-understand information on various IWM tools. Because more attention was given to self-explanatory illustrations than text, they are easily translated into other languages. So far, nine inspiration sheets have been published and several of these were translated into other languages (Figure 5). Besides information materials, several field days are organised every year at the locations where the IWMPRAISE experiments are conducted. Future tasks are to develop e-learning material packages on IWM and input for IPM training courses.

Table I. IWMPRAISE websites.

National Cluster

Denmark

United Kingdom

The Netherlands

France

Switzerland

Slovenia

Spain

Italy
Website or Webpage url / status at dead-line of this deliverable

https://www.landbrugsinfo.dk/Planteavl/Plantevaern/IPM/Sider/PI_I8_5I I I_IWMPRAISE_danske_udgivelser. aspx

(accessible also via a link from Danish IPM website http://www.dansk-ipm.dk)

www.iwm-uk.co.uk

www.wur.nl/iwmpraise

www.ecophytopic.fr/tr/programmes-de-recherche/europe/iwm-praise

www.agff.ch/deutsch/projekte/unkraut-management-eu-projekt-iwmpraise.html

www.ivr.si/raziskave-in-razvoj/projekt-iwmpraise-h2020/

www.uco.es/agroecologia/?page_id=902

http://www.venetoagricoltura.org/progetti/iwmpraise/ 


\section{FLEX-TINE WEED HARROWING IN SPRING CEREALS}

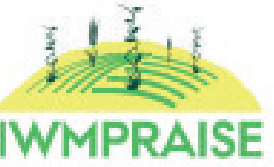

\section{DID YOU KNOW?}

Soil fillage with flex-tine weed harrow can control. with correct timing. up to $80 \%$ of annual weeds

\section{PREREQUISITES FOR SUCCESSFUL APPLICATION}

- Well levelled soils with few stones and crop residues

- Well prepared seedbed

- Workable soils, heavy clay soils may become too cloddy

- Uniform crop sowing at a constant depth of ca. $3-4 \mathrm{~cm}$

- Good growing conditions stimulating fast and vigorous crop growth

- Preferably sunny and dry weather during and after application

- Moderate weed pressure

- Preferably low numbers of tall-growing weed species, notably

- Cruciferous weed species

- Hemp-nettle (Galeopsis tetrahit)

- Annual grasses

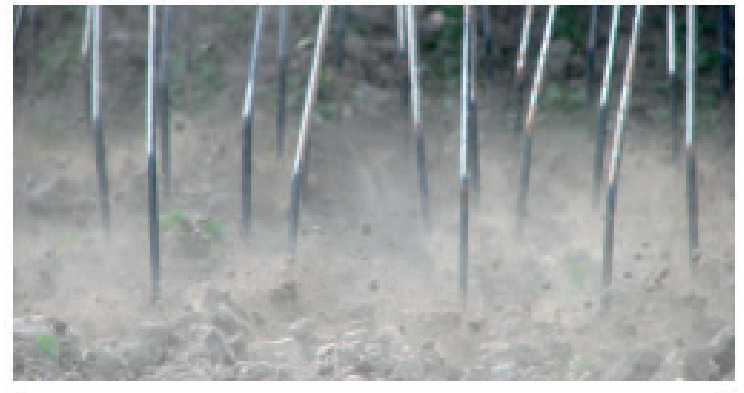

Figure 1 - Flex tines create soil disturbance which causes lethal uprooting and/or soil coverage of weeds.

(Photo by Jesper Rasmussen)

\section{IMPLEMENTATION}

- Pre-emergence harrowing at max. $2 \mathrm{~cm}$ soil depth shortly before crop emergence. Controls weed seedlings until the first leave stage.

- Post-emergence harrowing at the 3-4 crop leave stage (BBCH stage 13-14) but with the majority of weeds at the cotyledonous stage. Avoid covering more than $20 \%$ of the crop leaves with soil.

- Selective harrowing at the beginning of crop stem elongation (BBCH stage 30-31). Controls shallow and weakly rooted species with prostrate (e.g. Common Field-speedwell - Veronica persica), tufted (e.g. Common Chickweed - Stellaria media) or decumbent (e.g. Cleavers - Galium aparine) growth habits.

- Harrowing strategy. The three harrowing principles (pre, post and selective) can be combined for improving effectiveness against troublesome species such as Charlock (Sinapis arvensis) and annual grasses. Weed control effects reaching $80 \%$ against annual weeds is possible.

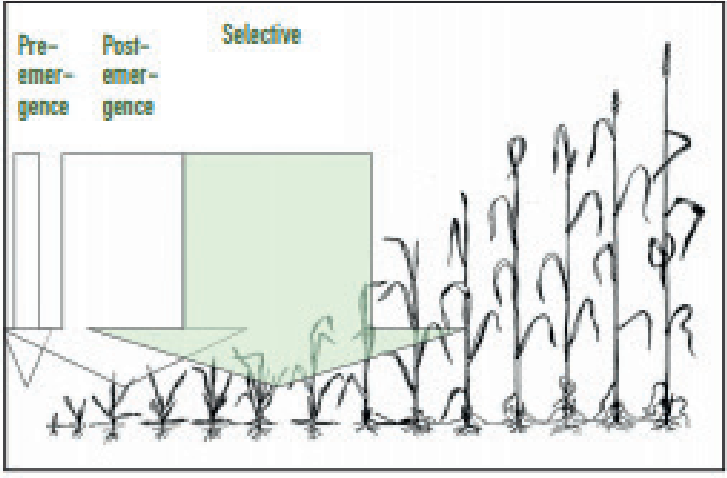

Figure 2 - The three principles of weed harrowing in spring cereals

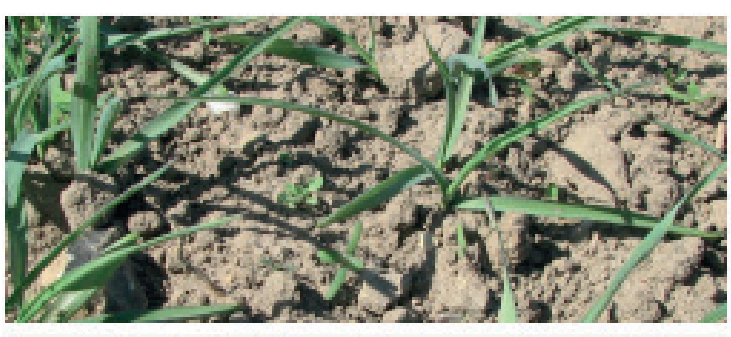

Figure 3 - A marked size difference between crop and weed plants is needed for successful conduction of weed harrowing: control of small weeds only requires low to moderate aggressiveness of harrowing which spares the crop. (Photo by Jesper Rasmussen)

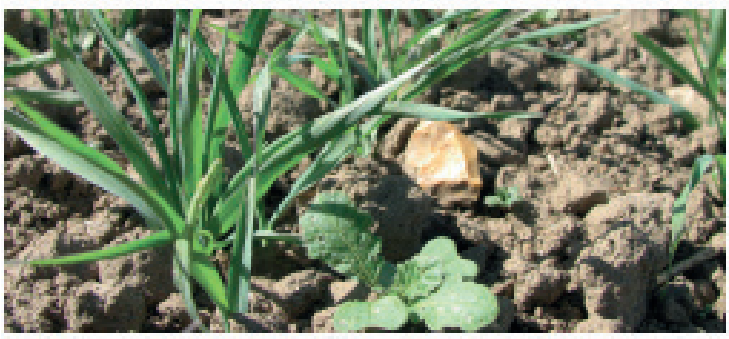

Figure 4 - A large Charlodk (Sinapis arvensis) requires aggressive harrowing settings for control - inevitably resulting in crop injuries. (Photo by Jesper Rasmussen)

\section{CONTACT}




\section{UKRUDTSHARVNING (STRIGLING) I VÅRSAED}

\section{VIDSTE DU?}

Jordbearbejdning med

en ukrudtsharve kan

med korrekt timing

bekæmpe op til $80 \%$ af

det enárige ukrudt

\section{FORUDSAETNINGER FOR SUCCESFULD ANVENDELSE}

- Plane marker med fã sten og afgroderester

- Bekvemt og godt sábed

- Jorde, som kan bearbejdes, stive lerjorde kan være vanskelige

- Ensartet sáning af afgrøden i en dybde på $3-4 \mathrm{~cm}$

- Gode vækstbetingelser som fremmer god vækst af afgroden

- Helst solrigt og tørt vejr under og efter harvningen

- Moderat ukrudtstryk

- Gerne fä højtvoksende ukrudtsarter, som f.eks.

- Korsblomstrede arter

- Hanekro

- Enárige grasser

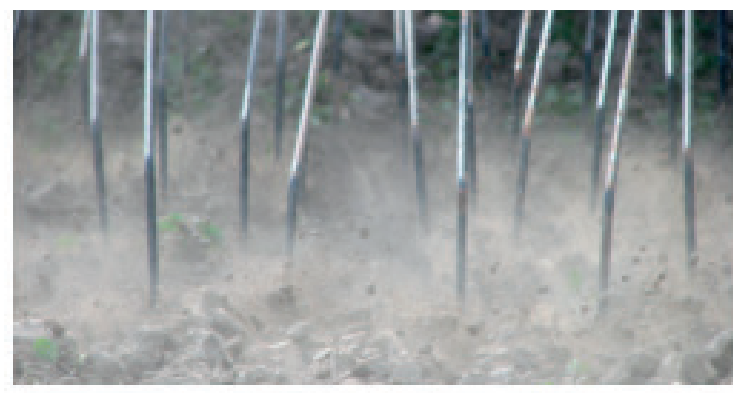

Figur 1: De fleksible harvetæender flytter rundt pă jorden, hvilket forärsager oprivning og/eller dæakning af ukrudtet (Foto: Jesper Rasmussen)

\section{SÅDAN GOR DU}

- Harvning for fremspiring (blindharvning) I maks. 2 $\mathrm{cm}$ dybde kort for afgrødens frem-spiring. Bekæmper fremspirende ukrudt frem til 1-bladstadiet.

- Harvning efter fremspiring på afgrødens 3-4 bladstadie (BBCH 13-14), hvor det meste ukrudt er pá kimbladstadiet. Undgå at dække mere end $20 \%$ af afgrødens blade med jord.

- Selektiv harvning ved begyndende afgrødestrækning (BBCH 30-31). Bekæmper ukrudt med overfladisk eller svagt rodsystem så som storkronet ærenpris, fuglegræs og burresnerre.
- Strategi for harvning: De tre principper (blindharvning. harvning efter fremspiring og selektiv harvning) kan kombineres for at forbedre effekten mod besværlige arter som agersennep og enárige græsser. Effekter pá op til $80 \%$ er opnåelige mod enårigt ukrudt.

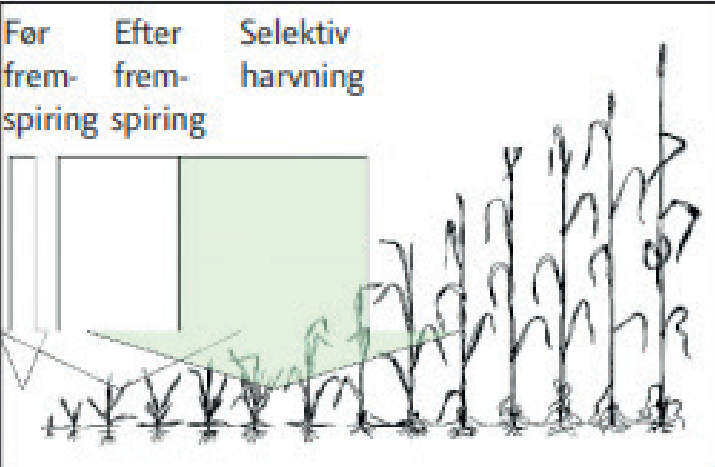

Figur 2: De tre principper for ukrudtsharvning i vărsaed

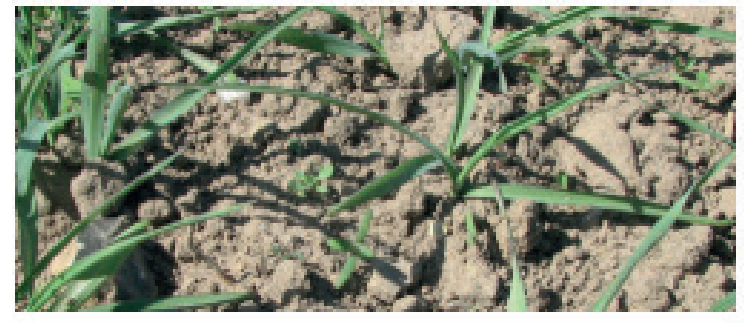

Figur 3: En betydelig storrelsesforskel mellem afgrode-og ukrudsplanter er nodvendig for succes med ukrudtsharvning: Bekæmpelse af smă ukrudtsplanter kraver kun lav til moderat aggresivitet af harvningen, hvilket skäner afgroden (foto: Jesper Rasmussen)

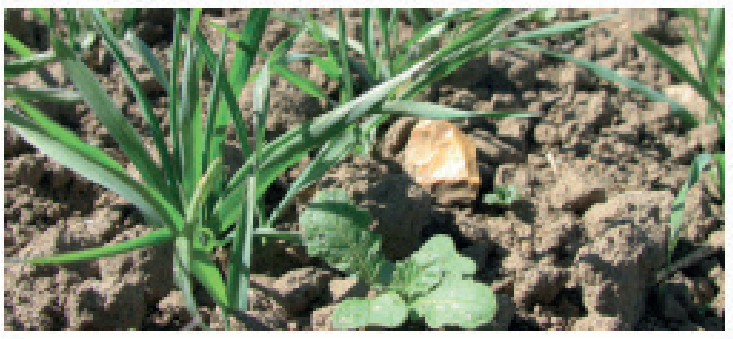

Figur 4: Store planter af agersennep kræever aggressiv harvning for bekzempelse, dette resulterer uundgăeligt i skader pá afgroden. Foto: Jesper Rasmussen

\begin{tabular}{|c|c|c|c|}
\hline KONTAKTPERSONER & $\begin{array}{l}\text { Jens Erik Jensen } \\
\text { Landbrug \& Fodevarer F. mb.A } \\
\text { SECES, Plantelnnovation } \\
\text { jnjoseges dk }+4587405438\end{array}$ & $\begin{array}{l}\text { AARHUS } \\
\text { UNIVERSITY }\end{array}$ & $\begin{array}{l}\text { Bo Melander } \\
\text { Aarhus University } \\
\text { bo.melandergagro.au.dk } \\
+4522283393\end{array}$ \\
\hline
\end{tabular}

Figure 5. Continued. 


\section{Parting Remarks}

IWMPRAISE is unique in the sense that it is the first major EU project focussing on weed management. An array of IWM activities has been organised all over Europe, some being new activities others a continuation of national activities. Two and a half years into the project, the first results are now available and are disseminated nationally but many outputs are still pending, as they will be based on overall assessments of the many results produced by the national clusters. Readers are encouraged to visit our website (www.iwmpraise.eu) to stay updated on the newest developments.

\section{References}

Melander B., N. Munier-Jolain, R. Charles, J. Wirth, J. Schwarz, R. van der Weide, L. Bonin, P.K. Jensen \& P. Kudsk (2013) European perspectives on the adoption of non-chemical weed management in reduced tillage systems for arable crops. Weed Technol. 127:231-240.

Munier-Jolain N.M., B Chavvel \& J Gasquez (2002) Long-term modelling of weed control strategies: analysis of threshold-based options for weed species with contrasted competitive abilities. Weed Res. 42:107-122.

Oerke E.-C. (2006) Crop losses to pests. Journal of Agric. Sci. 144:31-43.

Storkey J., S. Meyer, K.S. Still \& C. Leuschner (2012) The impact of agricultural intensification and land-use change on the European arable flora. Proc. R. Soc. B. 279:1421-1429.

Walsh M. (2018) Development of Harvest Weed Seed Control (HWSC) in Australian Cropping Systems. Outlooks on Pest Management 29:114-117

\section{Acknowledgement}

IWMPRAISE has received funding from the European Union's Horizon 2020 research and innovation programme under grant agreement No. 727321.

Per Kudsk is a professor and Head of the Crop Health Section at the Department of Agroecology, Aarhus University, Denmark. He has been involved in research on various aspects of weed management. In recent years, he has become increasingly involved in research activities focusing on Integrated Weed Management. He has led and been partner in several national and international research projects in the EU,Africa and South America. He is regularly involved in research based policy support on crop protection issues. He served as President of the European Weed Research Society from 2008 to 2009. In 2014, he was appointed Honorary Member of the Weed Science Society of America.

Mette Sønderskov is a weed scientist at Dept. of Agroecology at Aarhus University in Denmark. She works with weed biology and management strategies for better weed control in integrated weed management. Dissemination of results from research to end-users is supported with decision support tools for weed management.

Ludovic Bonin is an agronomist at Arvalis - Institut du Végétal, France, an applied field crop research organization. He has many years of experience in research and consulting on weed control (IWM, herbicides). His current research focuses on various issues related to alternative methods of weed control, knowledge of herbicides and the evolution of resistance in weeds.
Jose L. Gonzalez-Andujar is Head of the Weed Agroecology group in the Institute for Sustainable Agriculture (CSIC), Spain and Scientific Director of the International Laboratory on Global Change (LINCGlobal). His research focuses on the understanding the ecological principles that underpin weed agroecology. $\mathrm{He}$ is honorary member of the Weed Science Society of America (WSSA) and was formerly President of the Spanish Weed Science Society (SEMh) and Latinoamerican Association of Weed Science (ALAM).

Jens Erik Jensen is a senior specialist at SEGES, Denmark. His duties cover all aspects of crop protection, but his main work areas are integrated weed management and IPM in general.

Bo Melander is an Associate professor at the Department of Agroecology, Aarhus University, Denmark. His expertise is mainly on weed biology and nonchemical tactics to control weeds in conventional and organic arable cropping systems. Current research focuses on the exploration of new physical weed control methods, robotic weeding in sugar beet, the dynamics of perennial weeds in organic crops and mechanical weed control in grasses for seed production.

Anna Camilla Moonen is Assistant Professor in Agronomy and Field Crops at Scuola Superiore Sant'Anna in Pisa, Italy. She graduated at WUR, The Netherlands, and obtained her $\mathrm{PhD}$ at the University of Pisa, Italy. Her research focuses on agroecological co-design of sustainable cropping systems with a special interest in field margin management, the use of cover crops to manage weed communities, and functional agrobiodiversity in arable and horticultural cropping systems for integrated weed and pest management.

Marleen Riemens is head of the scientific research team Crop health that focuses on IPM in arable production systems at WUR. She studied Plant Breeding and Crop Protection at and obtained her PhD at the Crop and Weed Ecology Group of WUR in 2009. Current work focuses on the development and integration of sustainable solutions for crop protection issues in field crops. Warning and monitoring techniques, crop cultivation measures, biological control, and a conscious use of pesticides form the basics of the crop protection systems.

Maurizio Sattin is a Director of Research at the Institute for Sustainable Crop Protection of the Italian National Research Council of Italy.Academic and postdoc studies at Padua University on Agricultural Sciences and in particular on the ecophysiology of major arable crops. Visiting scientist at the University of Edinburgh. His current research focuses on various aspects of integrated weed management and herbicide resistance, mainly in arable crops and weeds.

Urs Schaffner is head of the 'Ecosystems Management' section at CABI in Switzerland and Affiliate Assistant Professor at the University of Idaho, USA. His research focuses on soil-plant-herbivore relationships, with a focus on biological invasions, biological control of weeds and grassland restoration. He is involved in a number of applied research projects in Europe, North America, Asia and Africa. Currently he leads an international project with ten research institutions on assessing the effects of invasive plant species in Eastern Africa and implementing management strategies that mitigate their negative impacts on ecosystems and rural livelihoods.

Jonathan Storkey is an agro-ecologist working at Rothamsted Research. He has a particular interest in balancing food production with the provision of other ecosystem services delivered by agricultural landscapes. As well as working on the IWMPRAISE project, he currently leads projects on the enhancement of natural pest control and pollination services on farms and quantifying the importance of crop diversity for sustainable production in sub-Saharan Africa. 